\title{
Çan Linyitlerinin Kendiliğinden Yanma Yatkınlıklarının Araştırılması
}

\author{
Cem ŞENSÖĞG̈T ${ }^{* 1}$, Özer ÖREN ${ }^{1}$ \\ ${ }^{1}$ Kütahya Dumlupınar Üniversitesi, Mühendislik Fakültesi, Maden Mühendisliği Bölümü, \\ Kütahya
}

$\ddot{\mathbf{O} z}$

Geliş tarihi: 25.07.2020 Kabul tarihi: 23.10 .2020

Yapılan bu çalışmada, Türkiye Kömür İşletmeleri (TKİ) bünyesinde faaliyet gösteren Çan Linyitleri İşletme Müdürlüğü (ÇLİ) açık ocak ve stoklarından temin edilen kömür numunelerinin kendiliğinden yanma karakteristikleri kesişim noktası metodu ile belirlenmiştir. Buna göre elde edilen sonuçlarda, kömürlerin ortalama sıcaklık artışlarının (OSA) $0,92-3,93{ }^{\circ} \mathrm{C}^{-1}$; tutuşma ya da kesişim noktası sıcaklıklarının (KNS) 150-182 ${ }^{\circ} \mathrm{C}$; yatkınlık indeksi (IFCC) değerlerinin ise 5,04-33,33 $\mathrm{dk}^{-1}$ arasında değiştiği yapılan deneylerde tespit edilmiştir. Sonuç olarak; 21 adet kömür örneğinin kendiliğinden yanmaya yatkınlıklarının "orta-yüksek" risk kategorisinde yer aldığı belirlenmiştir.

Anahtar Kelimeler: Çan Linyitleri İşletmesi, Kesişim noktası metodu, Kömürlerde kendiliğinden yanma, Linyit

\section{Investigation of Spontaneous Combustion Tendency of Çan Lignites}

\begin{abstract}
In this study, the spontaneous combustion characteristics of coal samples obtained from Çan Lignite Corporation's (ÇLC) open pit and stockpiles were determined by the crossing point temperature method. Accordingly, it was determined in the experiments that the average heating rates (AHR) of coals ranged from 0.92 to $3.93{ }^{\circ} \mathrm{C} \mathrm{min}^{-1}$; ignition or crossing point temperatures (CPT) from 150 to $182{ }^{\circ} \mathrm{C}$ and susceptibility index (IFCC) from 5.04 to $33.33 \mathrm{~min}^{-1}$. As a result, the liability of 21 coal samples to spontaneous combustion tendency was determined to be in the "medium-high" risk category.
\end{abstract}

Keywords: Çan Lignite Corporation, Crossing point temperature method, Spontaneous combustion of coal, Lignite

*Sorumlu yazar (Corresponding author): Cem ŞENSÖĞÜT, cem.sensogut@dpu.edu.tr 
Çan Linyitleri Işsletme Müdürlüğ̈̈ Açık Ocaklarında Üretilen Kömürlerin Stoklanması Sırasında Meydana Gelen Kendiliğinden Yanma Olayının Araştırılması

\section{GİRiş}

Dünya genelinde kömüre dayalı enerji teknolojilerinin yoğun bir şekilde kullanılması ve özellikle son yıllarda dünyanın en önemli gündem maddesi haline gelmiş olan küresel ısınma ve iklim değişikliği gibi konuların merkezini oluşturması, sera gazı yayılımı, iş sağlığı ve güvenliği konusundaki bilincin gün geçtikçe artması gibi nedenlerden dolayı kömürün kendiliğinden yanması konusu halen araştırmacıların yoğun ilgisi ile karşı karşıyadır. Kendiliğinden yanma özellikle madencilik alanında can ve mal kaybına sebebiyet vermesinin yanında sera gazı emisyonu ile tehlikeli eser elementler gibi çevresel felaketlere neden olan bir doğa olayıdır [1,2]. Kömür stokları da dahil olmak üzere termal güç istasyonlarında uzun süreli depolamalarda, açık işletmelerde, yeraltındaki eski üretim bölgelerinde, döküm sahalarında ve hatta uzun mesafeli kargo gemisi ya da tren gibi nakliye koşullarında dahi bu sorun ile karşılaşılabilmektedir [3-5].

Kendiliğinden yanma kaynaklı ocak yangınları; özellikle Çin, Amerika, Hindistan, Avustralya ve Almanya gibi kömür üreticisi ülkelerde başlıca sorun olarak göze çarpmaktadır [6]. Dünya üzerinde kendiliğinden yanma kaynaklı birçok yangın vakası envantere girmiştir. Polonya'da 1947-1966 yılları arasında kömür ocaklarında meydana gelen yangınların \%80'i kendiliğinden yanma sonucu gerçekleşmiştir [7]. Çin'deki maden ocaklarında gaz emisyonlarının \%40-60'1 ile yeraltı yangınlarının \%60'tan fazlası kendiliğinden yanma sonucunda oluşmaktadır [8]. Çin'de bulunan kömür madenlerinin \%56'sinın kendiliğinden yanma riski taşıdığı ifade edilirken, bu yangınlar neticesinde her y1l 20 milyon ton kömür yok olmaktadır [9]. Aynı şekilde Almanya'nın Ruhr havzasında yılda 10'dan fazla yangının kendiliğinden yanma kaynaklı çıktığı belirtilmiştir [10].

Hindistan' daki kömür yangınlarının ana merkezleri olan Jharia, Raniganj, Karanpura, Bokaro, Ibvalley, Talcher, Chirimiri, Singrauli and Singareni gibi kömür sahalarından özellikle Jharia ve
Raniganj bölgesindeki yangınların yaklaşık olarak \%70'inin kendiliğinden yanma merkezli olduğu rapor edilmiştir [11,12]. Avustralya'da sadece New South Wales bölgesinde 1960-1991 yılları arasında 125 kendiliğinden yanma olayı meydana gelmiştir [13]. 1970-1990 arası dönemde Güney Afrika'da rapor edilen 254 yangının üçte birinin kendiliğinden yanmadan kaynaklandığı öne sürülmüştür [14]. Özellikle Witbank ve Sasolburg kömür sahalarının kendiliğinden yanmaya yatkın oldukları dile getirilmiştir $[5,15]$.

Azalan kömür madencilik faaliyetlerine rağmen Çek Cumhuriyeti'nin Ostrava-Karvina kömür maden sahasında 1995-2002 yılları arasındaki periyotlarda kendiliğinden yanma sonucu oluşan 105, 2004-2006 arasında ise 54 olay kayitlara geçmiştir [16,17]. Dünyanın en büyük kömür üreticilerinden biri olan Amerika'da, 1990-1999 yıllarında açık işletme, yeraltı ve kömür hazırlama tesislerinde kendiliğinden yanma sonucu toplam 71 yangın meydana gelmiştir. Bu değer o yıllar arasında meydana gelen tüm ocak yangınlarının \% 16'sını oluşturmaktadır [18].

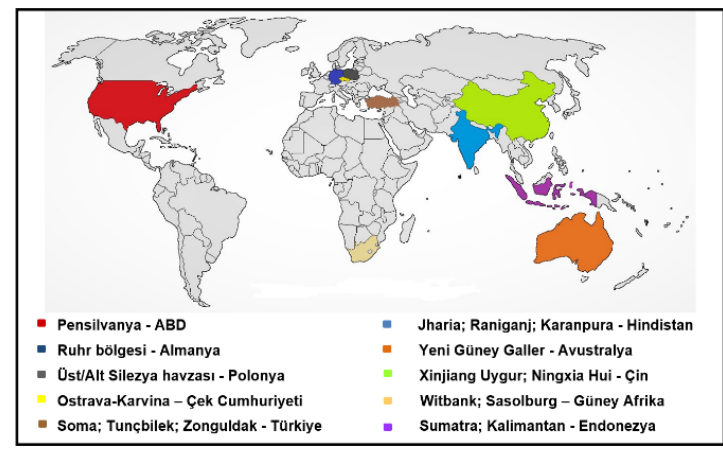

Şekil 1. Kendiliğinden yanma problemi ile karşılaşmış ülkeler ve yangın bölgeleri

Endonezya'da 1997 yılında turba depolarında gerçekleşen kendiliğinden yanma olayı, geniş ölçekte orman yangınlarına sebebiyet vermiştir [19]. Yıllık 35000 ton katı atık depolayan İsveç'te [20] 1988-1989 yılları arasında 217 kendiliğinden yanma kaynaklı yangın rapor edilmiştir [21]. Dünya genelinde kendiliğinden yanma problemi ile karşılaşmış belli başlı ülkeler ve bu ülkelere ait yanma bölgeleri Şekil 1'de verilmiştir. 
Genel olarak bakıldığında, ocak yangınları kişisel hatalar dışında kömürün kendi doğal mekanizması sonucunda oluşmaktadır. Kömür, havanın oksijeni ile temasa geçtiğinde okside olmakta ve bu oksitlenme sonucu isiveren bir reaksiyon oluşmaktadır. Eğer reaksiyon sonucu açığa çıkan 1s1, bulunan ortamdan uzaklaştırılabilirse bu durum "düşük sicaklık oksidasyonu" olarak adlandırılmaktadır. Fakat 1sı dağıtılamaz ya da uzaklaştırılamazsa "kendiliğinden 1sınma (selfheating)" adı verilen aşama gerçekleşmektedir [22]. Bu aşamada ortam 1sısı giderek yükselmekte ve buna paralel olarak ta kömürün sıcaklığ1 artmaya devam etmektedir. Kömürün eşik değerinin aşılmasıyla da kendiliğinden yanma olayı ortaya çıkmaktadır [23]. Geçmişten günümüze kadar maddi ve manevi kayıplara yol açan, çok sayıda insanın ölümüne sebep olan kendiliğinden yanma olayının ve kömür oksidasyonunun nedenlerinin kesin bir şekilde ortaya konulması, yanma mekanizmasının aydınlatılması ve kendiliğinden yanmanın doğabilecek her türlü olumsuz sonucunun iyi bir şekilde kestirilerek gerekli önlem ve tedbirlerin alınması hayati önem taşımaktadır. $\mathrm{Bu}$ amaçla çalışma kapsamında literatürde daha önce kendiliğinden yanma yatkınlıkları belirlenmemiş olduğu tespit edilen TKİ Çan Linyitleri İşletmesi Müdürlüğü'ne ait IR:3378 ruhsat numaralı açık ocak işletmesi kömür sahasının ve kömür stoklarının kendiliğinden yanma yatkınlıkları "kesişim noktası metodu" kullanılarak belirlenmiştir.

\section{KÖMÜRÜN KENDILİĞINDEN YANMA MEKANIZMASI}

Kömürlerin kendiliğinden yanma mekanizmaları üzerinde 17. yüzyıldan beri çalışmalar yapılmaktadır. Bu olayı açıklamak üzerine birbirinden farklı teoriler geliştirilmiștir. $\mathrm{Bu}$ teorilerden bazıları; pirit teorisi, bakteri teorisi, fenil reaksiyonu, serbest radikal reaksiyonu, hidrojen reaksiyonu, aktivasyon grup reaksiyonu ve kömür-oksijen etkileşimi teorisidir. $\mathrm{Bu}$ teoriler arasında araştırmacılar tarafından en çok kabul gören yaklaşım kömür-oksijen etkileşimi teorisidir [24].
Bu teoriye göre kömür ve oksijen arasında gelişen reaksiyonlar "direk yanma" ve "kemisorpsiyon" olmak üzere 2 ana aşamada gerçekleşmektedir. "Direk yanma" adı verilen bu aşamada; kömür oksijen arasında gerçekleşen reaksiyon neticesinde $\mathrm{CO}, \mathrm{CO}_{2}$ ve $\mathrm{H}_{2} \mathrm{O}$ gibi oksidasyon ürünleri açı̆̆a çıkmaktadır [25,26]. "Kemisorpsiyon" aşaması ise; birbirini izleyen 4 alt aşamadan oluşmaktadır. Bu aşamalar şu şekilde özetlenebilir: 1) oksijenin fiziksel adsorpsiyonu, sıcaklıkta artış; 2) kimyasal adsorpsiyon $\quad\left(50 \quad{ }^{\circ} \mathrm{C} \quad\right.$ üzeri $), \quad$ oksijenetik hidrokarbonların ya da peroksi bileşiklerin üretimi; 3) altere olmamış kömürün eş zamanlı oksidasyonu ile birlikte kendiliğinden yanma sıcaklığına ulaşıldığında $\left(70{ }^{\circ} \mathrm{C}\right.$ üzeri) oksijenetik hidrokarbonların bozuşması; ve 4) ilk üç maddedeki işlemlerin tümü, tipik olarak tutuşma eşiği olarak tanımlanan $150{ }^{\circ} \mathrm{C}$ 'den yüksek sicaklıklara neden olması durumunda kendiliğinden yanma adı verilen olayın ortaya çıkması [27]. Söz konusu tutuşma eşiği kömürün rankına bağlı olarak en düşük ranktaki kömür için $130{ }^{\circ} \mathrm{C}$ gibi bir değerde olabildiği gibi turba için daha düşük değerlerde bile izlenebilir. $\mathrm{Bu}$ bağlamda, $60-80{ }^{\circ} \mathrm{C}$ aralığı kritik olarak kabul edilmektedir [28]. Şekil 2'de kömür oksidasyonunda gerçekleşen genel reaksiyon aşamaları görülmektedir [29].

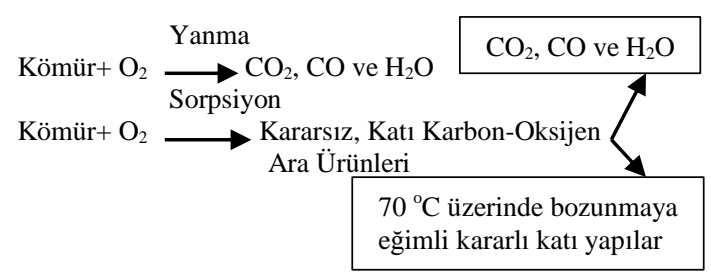

Şekil 2. Kömür oksidasyonunda gerçekleşen reaksiyon aşamaları

Kömür oksidasyonunun ilk aşaması kömür yüzeyindeki aktif bölgelerdeki oksijenin kimyasal olarak tutunması (kemisorpsiyon) ile meydana gelmektedir. $40{ }^{\circ} \mathrm{C}$ 'nin altında gerçekleşen bu reaksiyon aşamasında kömür ve oksijen molekülleri arasındaki etkileşim kömür gözenekleri içindeki oksijenin fiziksel adsorpsiyonundan kaynaklanmaktadır [30]. 


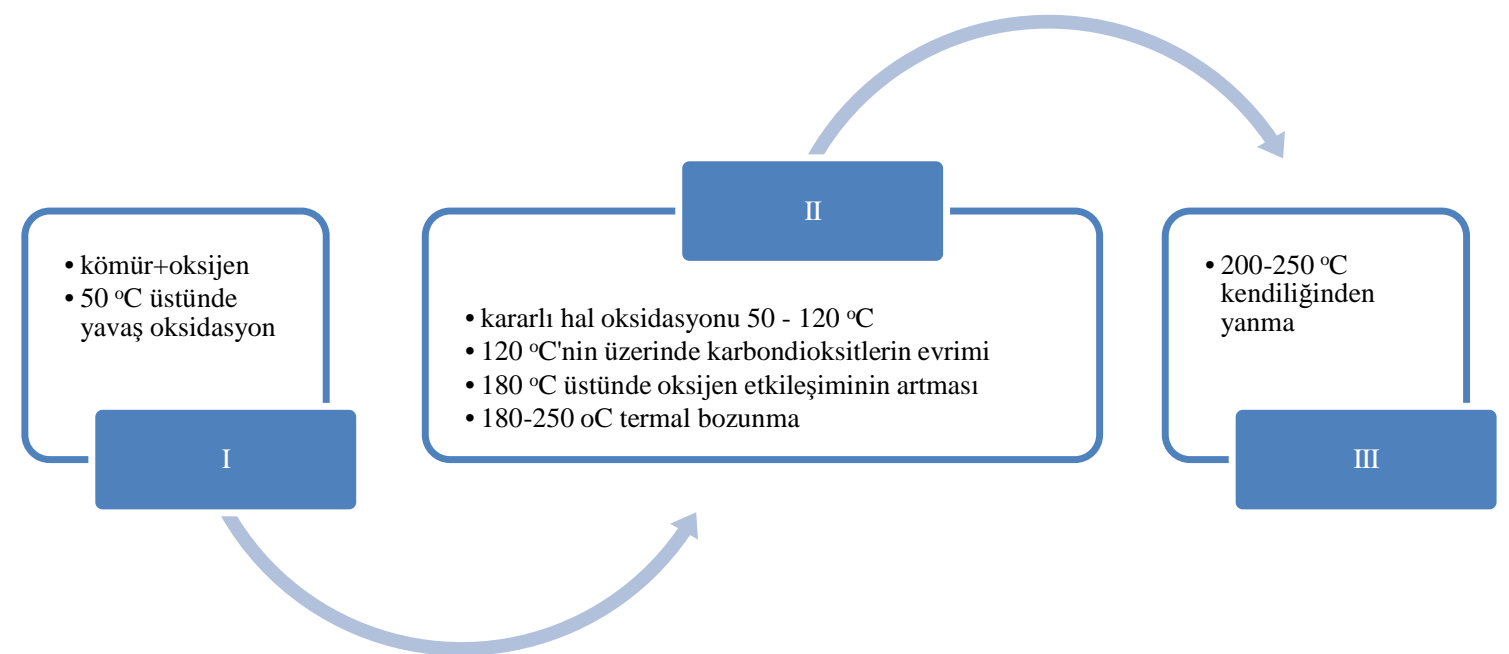

Şekil 3. Sıcaklığa bağlı olarak kömür oksidasyonunda meydana gelen değişimler

Şekil 3'te sicaklığa bağlı olarak kömür oksidasyonunda meydana gelen değişim aşamaları gösterilmektedir [31].

Kömür ve oksijen molekülleri arasındaki reaksiyon dizileri sürecin genelinde endotermik bir nitelik gösterse de, düşük sıcaklıklarda ekzotermik karakterdedir [32]. Bu reaksiyon aşamaları neticesinde farklı özelliklere sahip karbon-oksijen bileşikleri oluşmaktadır. Bu bileşikler "kararsız", "kararlı" ve "reaktif olmayan" olmak üzere üç sınıfa ayrılabilmektedir. Peroksijen, hidroperoksit ve hidroksil türleri kararsı bileşikleri oluştururken; kararlı bileşikleri karbonil ya da karboksil içeren türler temsil etmektedir.

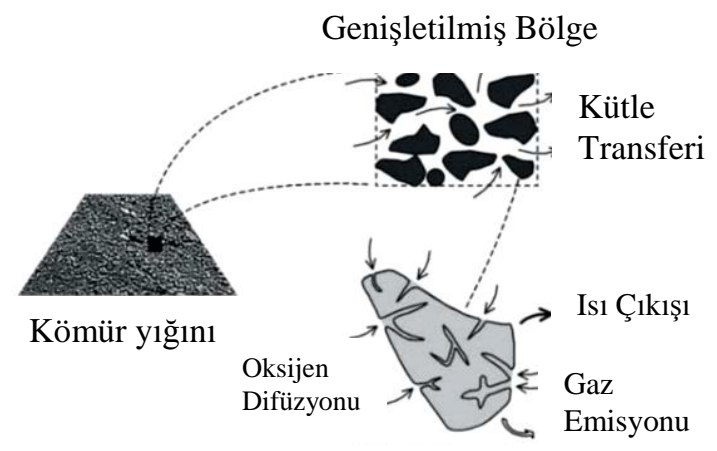

Kömür Tanesi
Reaktif olmayan bileşikler ya da diğer adı ile hümik asitler; anhidritler, etherler ya da esterler olarak tanımlanmaktadır. Sonraki aşamalarda bahsedilen kararsız oksijenli bileşikler ayrıșarak gaz ürünlerine ve kararlı bileşiklere dönüşmektedir. Kararlı bileşiklerin de bozuşmasıyla birlikte oksidasyon için yeni aktif bölgeler oluşmaktadır [33]. Şekil 4'te kömür parçasına oksijen difüzyonu ve sonrasında gerçekleşen olaylar görülmektedir [34].

\section{KÖMÜRÜN KENDILIIĞINDEN YANMASINI ETKILEYEN FAKTÖRLER}

Kömürün karmaşık fiziko-kimyasal bir yapıya sahip olması, aynı damara ait kömür numunelerinin bile zamanı geldiğinde farklı özellikler içermesi, kendiliğinden yanma olayının farklı açılardan ele alınması gerekliliğini ortaya çıkarmıştır. Kömürün birden çok özelliğinin farklı şekillerde etkilediği kendiliğinden yanma prosesinde etkili olan parametreler, genel olarak iç (endojen) ve dış (ekzojen) faktörler olmak üzere ikiye ayrılmaktadır [35-39]. Çizelge 1'de kendiliğinden yanmada etkili olan parametreler ayrıntılı olarak gösterilmiştir.

Şekil 4. Kömür oksidasyonunda gelişen olaylar 
Çizelge 1. Kömürün kendiliğinden yanmasında etkili olan parametreler

\begin{tabular}{|c|c|c|c|}
\hline \multicolumn{2}{|c|}{ İç (endojen) faktörler } & \multicolumn{2}{|c|}{ Diş (ekzojen) faktörler } \\
\hline Kömür özellikleri & Jeolojik özellikler & Atmosferik koşullar & $\begin{array}{c}\text { Madencilik ile ilgili } \\
\text { faktörler }\end{array}$ \\
\hline Kömürleşme derecesi & & & Üretim yöntemi \\
İlerleme hızı \\
Petrografik yapı & Damar kalınlığı & & Topuk koşulları \\
Nem içeriği & Damar eğimi & & Tavan koşulları \\
Mineral madde içeriği & Göçme özelliği & Sıcaklık & Taban yolu koşulları \\
Tane boyutu & Fay ve arızalar & Nem & Hava kaçakları \\
Pirit içeriği & Derinlik & Oksijen derişimi & Kömür kayılpları \\
Fiziksel özellikler & Jeotermik gradyan & & Çalış1lmış sahalar \\
Bakteriler & & & Dolgu \\
& & & Havalandırma basıncı \\
& & & Hava nemliliği \\
\hline
\end{tabular}

\subsection{Kömürleşme Derecesi}

Kömürün rank1; turbadan meta-antrasite kadar kömürdeki organik metamorfizma derecesi olarak tanımlanmaktadır ve kömürün sınıflandırılmasında ayırt edici bir rol oynamaktadır. Genel olarak bakıldığında; düşük ranklı kömürler daha fazla reaktif nem, oksijen ve uçucu madde içerdiklerinden dolayı, yüksek ranklı kömürlere oranla kendiliğinden yanmaya daha yatkındırlar [40]. Kömürleşmenin ilerlemesi ile birlikte, kömür yapısındaki aromatikliğin artması ve fonksiyonel grupların azalması ile bu az sayıdaki fonksiyonel grupların ancak yüksek enerjilerde oksitlenebilmesi de ayrı bir etken olarak gösterilmektedir [41]. Literatürde artan kömürleşme derecesi ile birlikte kömürün oksijen tüketiminin azaldığı belirtilmiştir [33,42]. Bunun dışında, düşük ranklı kömürlerde kömür yapısındaki gözeneklerin artması ve buna bağlı olarak da oksijen moleküllerinin bağlanmak için daha rahat yüzeyler bulması da bir etken olarak gösterilmektedir [43].

\subsection{Nem İçeriği}

Kömürler, kömürleşme derecelerine göre farklı oranlarda nem içerebilmektedirler. Turbalar \%80-90 oranında nem içerebilirken; linyit ve kahverengi kömür gibi düşük ranklı kömürler $\% 30-70$ ve sert ya da bitümlü kömürler ise \%10 ve daha az oranlarda neme sahiptirler [44]. Kömürdeki nem, suyun bulunuş şekline göre yüzey nemi ve iç nem olmak üzere ikiye ayrılmaktadır. Yüzey nemi; adhezyon nemi, taneler arası nem ve adsorpsiyon nemi olarak alt sınıflara ayrılabilmektedir [45]. Yüzey nemi; kömürle birlikte doğal olarak bulunmayan, kömüre yapısındaki kırık ve çatlaklar aracılığı ile girmiş olan nemi ifade eder [37]. Kömürdeki nem içeriğinin oksidasyona ve kendiliğinden yanmaya etkileri üzerinde farklı görüşler ileri sürülmektedir. Genel olarak araştırmacılar tarafından kömürün oksijen tüketiminin maksimum olduğu değer için kritik bir nem aralık değerinin var olduğu; bu nem aralığının aşağısında ya da yukarısında olan kömürler için oksijen tüketim oranlarının azaldığı ifade edilmiştir [33]. Bu teoriye karşı çıkan ve söz konusu testlerin altere olmuş kömürler üzerinde gerçekleştiğini iddia eden çalışmalarda bulunmaktadır [46]. Panaseiko [47], nem içeriğinin \%5-10 arasında olduğu durumlarda oksidasyonun en hızlı seviyeye ulaştığını belirtmiştir. Yeni Zelanda alt bitümlü kömürleri üzerinde yapılan bir diğer çalışmada, oksidasyonun maksimuma ulaştığı nem sınırı \%7-17 olarak araştırmacılar tarafından tespit edilmiştir [48]. Kadioglu ve Varamaz [49], 96 saat boyunca farklı derecelerde nemlendirilen ve atmosferik ortamda kurutulan numuneler üzerinde kesişim noktası metodunu kullanarak, kendiliğinden yanma yatkınlık ölçümleri yapmışlar ve artan nemin tutuşma 
Çan Linyitleri Işsletme Müdürlüğ̈̈ Açık Ocaklarında Üretilen Kömürlerin Stoklanması Sırasında Meydana Gelen Kendiliğinden Yanma Olayının Araştırılması

sıcaklığı değerlerini yükselttiğini, kendiliğinden yanma riskini azalttığını vurgulamışlardır.

\subsection{Tane Boyutu}

Kömür oksidasyonu ve bunun sonucunda meydana gelen kendiliğinden yanma prosesi genel olarak düşünüldüğünde kömürün yüzeyinde ve gözeneklerinde gerçekleşen bir olaydır. Günümüze kadar yapılan araştırmalarda; kömürün tane boyutunun küçülmesi sonucu yüzey alanının arttığ1 ve oksijen ile temas edecek ek yüzeylerin oluşmasina firsat vermesinden dolayı kendiliğinden yanmayı arttırıcı rol üstlendiği ifade edilmiştir [50,51]. Küçük ve arkadaşları [52] Aşkale linyitlerinin kendiliğinden yanma karakteristikleri üzerine yaptıkları çalışmada; üç farklı tane boyutuna sahip $(-125 \mu \mathrm{m} / 125 \mu \mathrm{m}-$ $250 \mu \mathrm{m} / 250 \mu \mathrm{m}-850 \mu \mathrm{m})$ linyit örnekleri arasında en düşük tutuşma sıcaklığı değerinin $-125 \mu \mathrm{m}$ tane boyutuna sahip numune olduğunu ve aynı tane boyutunda oksijen fonksiyonel grupların arttığını ispatlamışlardır.

\subsection{Mineral Madde İçeriği}

Kömürün mineral içeriği, kendi organik yapısının dışında kalan elementlerin toplamı olarak ifade edilmektedir. Kömürün içerdiği mineraller genel olarak "bünye mineral maddesi" ve "diş mineral madde" olarak ikiye ayrılmaktadır. Bünye mineralleri kömürün inorganik yapısında bulunan ve kömürden uzaklaştırılamayan minerallerdir. D1ş mineraller ise, kömürün oluşumundan sonra kömüre katılan, kömürden cevher zenginleştirme yöntemleriyle ayrılabilen minerallerdir. Majör mineraller olarak adlandırılan bu mineralleri; illit, kaolinit, montmorillonit, kalsit, siderit, dolomit, ankerit, kalsiyum, demir, magnezyum, pirit mineralleri ve kuvars olarak sıralamak mümkündür [37].

Genel olarak kömürde mineral maddenin artması yapısındaki karbon miktarını azaltacağından yüksek mineral madde içeriğinin kömürün kendiliğinden yanmasını azaltacağını söylemek mümkündür. Bunun haricinde geçmişte yapılan çalışmalarda, kömür bünyesinde bulunan kireç, soda ve demir bileşiklerinin oksidasyonu hızlandırıcı; alüminyum, silis gibi minerallerin ise süreci yavaşlatan etkiye sahip oldukları belirtilmiştir [53].

\subsection{Pirit İçeriği}

Kömür yapısında bulunan piritin $\left(\mathrm{FeS}_{2}\right)$ oksidasyonda katalizör etkisi yarattığ 1 ve kendiliğinden yanma üzerinde hızlandırıcı etkisinin olduğu daha önceki çalışmalarda belirtilmiştir [54,55]. Ayrıca kömür bünyesindeki piritin oksidasyon sonucu şişmeye maruz kaldığı ve bu şişme sonucunda oluşan iç kırıklanmaların kömür yüzeyinde yeni reaktif yüzeyler yarattığı tespit edilmiştir [56]. Literatürde piritin kendiliğinden yanmada etkin bir rol oynayabilmesi için bu oranın \%2'nin üzerinde olması gerektiği ifade edilmiştir [57]. Bu görüşün aksine piritin kendi başına bir şey ifade etmediği ve oksidasyonda katalizör görevini yerine getirmesi için belli bir oranda neme ihtiyaç duyduğunu, kuru numuneler üzerinde yapılan testlerde piritin tek başına oksidasyona katkı sağlamadığını öne süren çalışmalar da bulunmaktadır [58].

\subsection{Petrografik Yapı}

Yapıs1 itibariyle heterojen bir madde olan kömürde, metamorfizma sonucu farklı yapıda oluşumlar meydana gelmektedir. Oluşan bu bant görünümündeki yapılara "litotip", litotipleri oluşturan ve sadece mikroskobik yollarla görülebilen mikro ölçekteki yapılara ise "maseral" adı verilmektedir.

Kömür petrografisinin kendiliğinden yanma üzerinde etkileri de literatürde araştırmacıların ilgisini çeken konular arasında yer almaktadır. Liptinit ve vitrinit gibi reaktivitesi yüksek maserallere sahip kömürlerin kendiliğinden yanmaya yatkın oldukları genel olarak kabul edilmektedir [59]. Vitrinitin moleküler yapısında inertitten çok daha fazla aromatik olmayan bileşikler bulunmaktadır. Ayrıca vitrinit, inertite göre daha düşük aktivasyon enerjisine sahip olup birim alanı başına yüksek miktarlardaki oksijeni, oksidasyonun düşük sicaklıktaki aşamalarında daha hızlı ve kolay bir şekilde adsorbe edebilmektedir [60]. Yapılan araştırmalarda; 
vitrinitin kömürün rankından bağımsız olarak kendiliğinden yanma açısından en reaktif maseral olduğu ifade edilmiştir [61-63].

\subsection{Uçucu Madde İçeriği}

Kömürdeki uçucu madde; kömürün oksijensiz ortamda 1sitıldıktan sonra yapısından çıkan hidrojen, karbonmonoksit, metan ve hidrokarbonlar, katran buharları, karbondioksit ve su buharı gibi gazların tümü olarak ifade edilebilir [36]. Schmidt \& Elder [64] oksidasyon üzerinde uçucu maddenin etkisini belirlemek amacı ile farklı uçucu madde oranlarına sahip 8 adet kömür örneği üstünde $100{ }^{\circ} \mathrm{C}$ 'nin altında deneyler gerçekleştirmişlerdir. Artan uçucu madde oranı ile birlikte kömür oksidasyonunun arttığını, \%38 uçucu maddeye sahip kömürün $\% 18$ uçuculu kömüre göre 3 kat daha hızlı oksitlendiğini tespit etmişlerdir.

\subsection{Kömür Sıcaklığı}

Kömür havanın oksijeni ile temasa geçtiği anda kendiliğinden yanmanın ilk aşaması olan fiziksel adsorpsiyon işlemi başlamakta ve kömürün sıcaklığı reaksiyon rejimine paralel olarak artmaya devam etmektedir. Yapılan çalışmalarda, artan kömür sicaklığı ile birlikte oksijen tüketim oranının arttığı ve kendiliğinden yanma sürecini hızlandırıcı bir etkiye yol açtığı ifade edilmiştir. Chamberlain ve arkadaşları [65,66] yaptıkları incelemelerde; oksidasyon işleminin kritik sıcaklık adı verilen sıcaklığa kadar yavaş bir seyirde devam ettiğini, bu değerin aşılması ile birlikte kömürden çıkan gaz artış hızının yükseldiğini belirtmişlerdir. Bahsedilen kritik sıcaklık değerinin kömürleşme derecesine bağlı olarak $30-70^{\circ} \mathrm{C}$ arasında değiştiği araştırmacılar tarafından elde edilen bulgular arasındadir.

\subsection{Dış Faktörler}

Kömürlerin oksidasyonunda ve buna bağl1 olarak meydana gelen kendiliğinden yanma davranışında sadece kömürün bünye özellikleri etkili olmamaktadır. Kömür oksidasyonu, kömürün fiziksel ve kimyasal özellikleri ile birlikte atmosferik koşullardan başlayan ve kömürün üretim yöntemine göre çeşitlenebilen çok geniş yelpazeli ekzotermik bir reaksiyondur. Şüphesiz ki kömürün kendiliğinden yanmasında en önemli etkenlerden bir tanesi kömürün oluştuğu havza itibari ile gösterdiği jeolojik yap1 değişikliğidir. Bazı durumlarda aynı kömür damarına mensup fakat farklı damar kalınlığındaki kömürler arasında dahi kendiliğinden yanma süreci farklı bir aşamada ilerleyebilmektedir. Genel olarak kömür damarının kalınlığı arttıkça kömürün 1sıl iletkenliği azalmakta ve kömürdeki 1sı birikimi fazlalaşabilmektedir. Kalın kömür damarlarının kazısında sıkça uygulanan blok göçertmeli yöntemlerde, göçük kısmında üretilmeden terk edilmiş kırıklı yapıya sahip kömür parçaları kendiliğinden yanmaya zemin hazırlamaktadır [67-69]. Literatürde 5 m'den fazla kalınlığa sahip kömür yataklarının kendiliğinden yanmaya daha yatkın olduğu ifade edilmiştir [70]. Artan derinlikle birlikte kömürün kendiliğinden yanma riski de paralel şekilde artmaktadır. Derin ocaklarda kömür üzerine binen kaya basıncı, bırakılan topukların ve özellikle kazı arınındaki kömür parçalarının kırılmasına ve çatlamasına yol açmaktadır. Bu kırık ve çatlaklar kömürün oksijen ile teması için serbest yüzeyler oluşturmaktadır [71].

Bunun dışında derinliğin artması sonucunda jeotermal gradyanın da buna bağlı olarak artacağı, bu artış neticesinde kömür ve çevre kayaçların 1sısının fazlalaşacağı ve bunun da kendiliğinden yanma için uygun bir ortam hazırlayacağ1 literatürde belirtilmiştir [53]. Genel olarak, 30-100 ${ }^{\circ} \mathrm{C}$ arasındaki sicaklıklarda her $10{ }^{\circ} \mathrm{C}$ 'lik sıcaklık artışı neticesinde kömürün oksidasyon hızı ortalama 2,2 kat artmaktadır [72]. Ocak içerisindeki atmosferik koşullar açısından incelendiğinde, kendiliğinden yanma üzerinde havadaki nem miktarının etkisi de kendiliğinden yanmayı etkileyen parametreler arasında gösterilmektedir. Kömür yüzeyine etkiyen nemli havanın kuru havadan 2,5 kat daha fazla 1sı ürettiği ifade edilmiştir [73]. Havadaki nemin kısmi basıncının yüksek olması durumunda kömür ve atmosferik hava arasında nem alışverişi olmakta ve yoğunlaşma sırasında açığa çıkan 1s1 kömürün sıcaklığının artmasına ve kendiliğinden yanma riskinin yükselmesine neden olabilmektedir [37]. Ayrıca havadaki nemin \%10-40 arasında olduğu 
Çan Linyitleri Işsletme Müdürlüğ̈̈ Açık Ocaklarında Üretilen Kömürlerin Stoklanması Sırasında Meydana Gelen Kendiliğinden Yanma Olayının Araştırılması

koşulda oksijen moleküllerinin kömüre tutunma oranının en düşük seviyede olduğu tespit edilmiştir [52].

Kendiliğinden yanma sonuç olarak, kömürün hava ile temas etmesi neticesinde oluşan bir reaksiyondur. Bundan dolayı ocak içerisine gönderilen hava miktarı kendiliğinden yanma davranışı ve seyiri açısından hayati bir öneme sahiptir. Rus araştırmacılar \%17'den fazla oksijen derişimine sahip 0,1-0,9 $\mathrm{m} / \mathrm{dk}$ akış oranındaki havalandırmanın riskli olduğunu ifade etmişlerdir [70].

İlerletimli uzunayak yöntemi göçük arkasında kalan kömürlerin sürekli hava akımına maruz kalmasından dolayı geri dönümlü yönteme kıyasla kendiliğinden yanma açısından daha tehlikeli bir yöntemdir. Geri dönümlü yöntemde taban yolları kömürün içerisinde olduğundan hava kaçacak herhangi bir yol bulamamakta ve böylece hava kaçakları minimuma indirgenebilmektedir. Topuklu yöntem uygulanan kömür ocaklarında ise, topukların tavan basıncına dayanamayarak kırık ve çatlaklar oluşturması kendiliğinden yanma için uygun zeminin oluşmasına neden olmaktadır. Bundan dolayı fizibilite aşamasında bırakılacak topuk boyutları ve geometrisinin dikkatli bir çalışma yapılarak seçilmesi gerekir [37,74].

\section{4. ÇAN LINYITLERİ IŞLETME MÜDÜRLÜĞÜNE KÖMÜRLERIN KENDILIİGINDEN YANMAYA YATKINLIKLARININ BELİRLENMESI}

\section{1. Çan Linyitleri İşletme Müdürlüğü (ÇLİ)}

Çan Linyitleri İşletme Müdürlüğü IR:3378 no’lu ruhsat ile Çanakkale ili, Çan ilçesi bölgesinde TKI'ye bağlı olarak linyit işletmeciliği yapmaktadir.

Açık işletme tekniği ile üretim yapılan sahada bir adet pasa döküm alanı bulunmaktadır. İşletme 2018 yılı itibariyle 2.881.920 ton tüvenan kömür üretirken 30.863.003 ton pasa üretmektedir. Ayrıca işletmede iki ayrı kömür stok sahası bulunmakta ve bu stok sahalarında 700.570 ton kömür depo edilmektedir [75].

\section{2. Örneklerin Temin Edilmesi}

Çalışma kapsamında Çan Linyitleri İşletme Müdürlüğü IR:3378 ruhsat no'lu sahasında bulunan açık işletme ve stok sahasında örnekleme çalışmaları yapılmıştır. Örnekleme aşamasında işletmeye ait delik makinesinden yararlanılmış olup, kömür damarının farklı derinliklerinden ve stoktan numuneler alınmıştır. Delik makinesi ile açılan deliklerin yüzeyde toplanan kırıntı ve parçalarından konileme-dörtleme yöntemi ile numune azaltılmış ve kömür örnekleri deneylerde kullanılmak üzere çuvallara konularak KDPÜ Maden Mühendisleri Laboratuvarına getirilmiştir (Şekil 5a ve 5b). Örneklerin alındığı noktalar Şekil 6'da verilen harita üzerinde işaretlenmiştir.

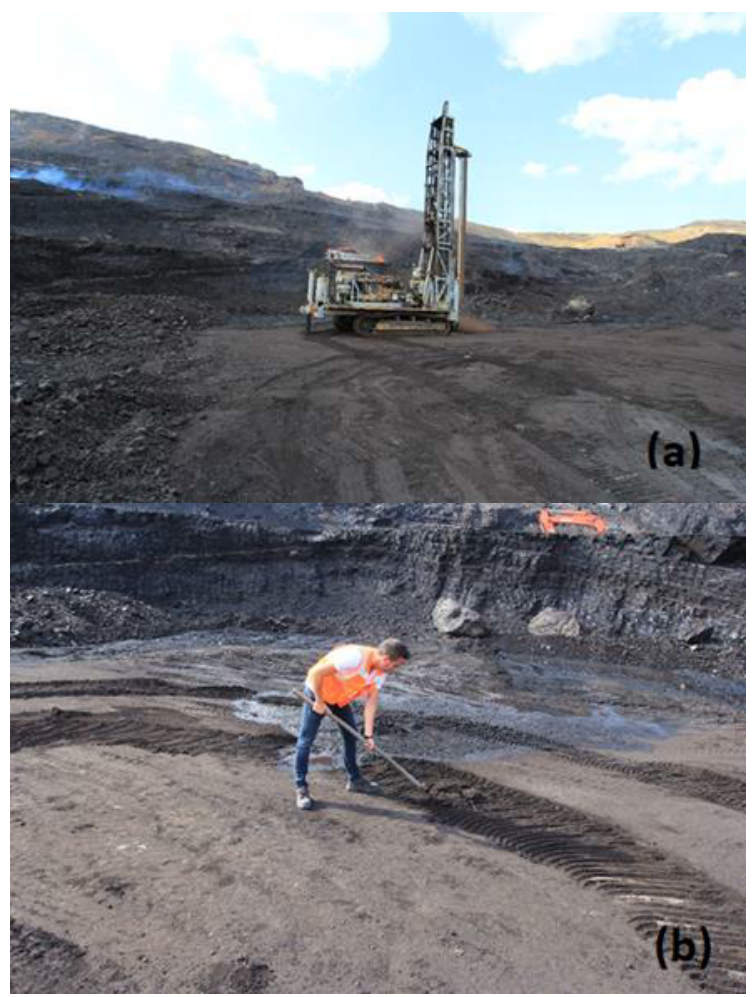

Şekil 5. Kömür sahasından numune alma (a) ve azaltma işlemi (b) 


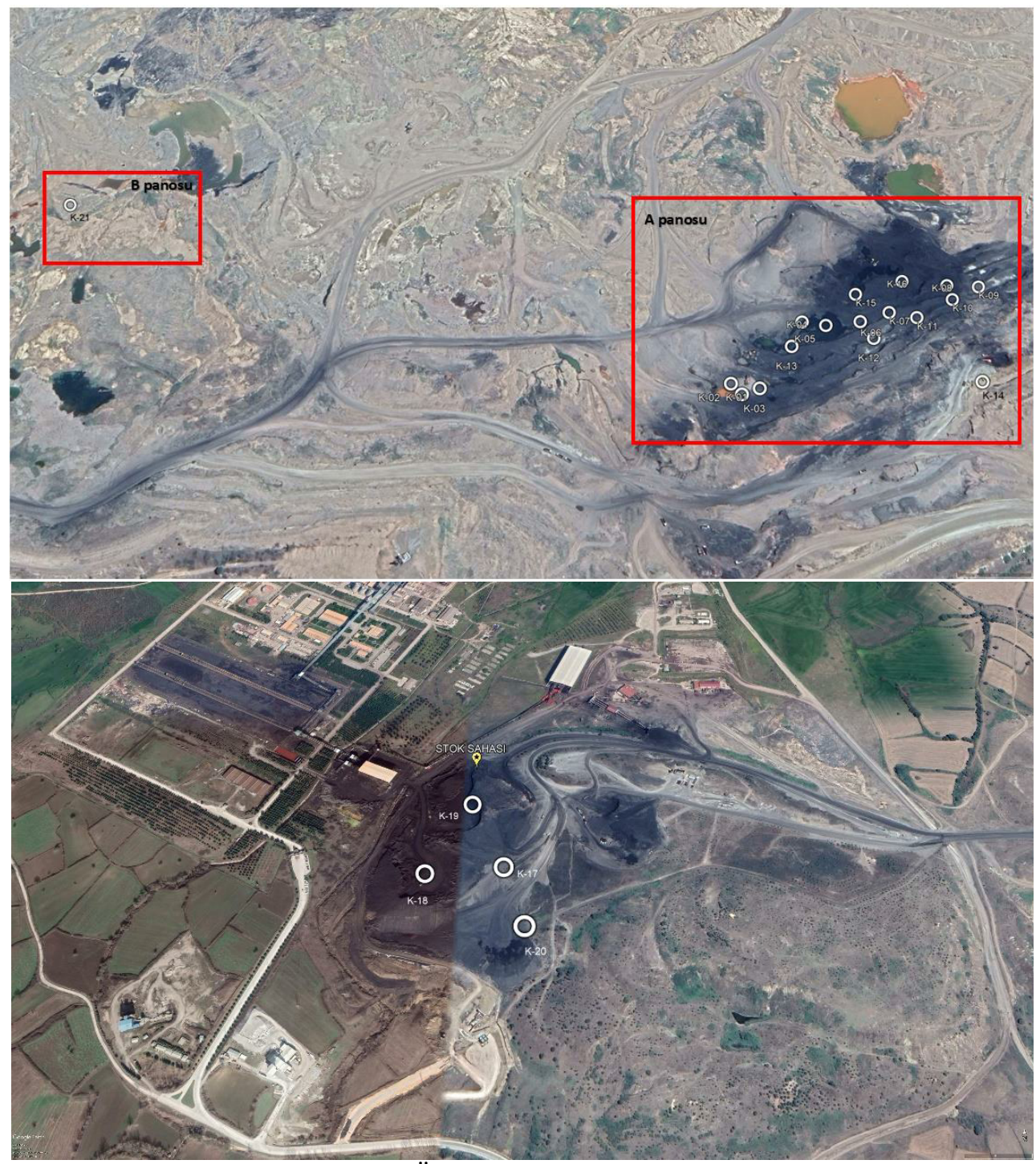

Şekil 6. Örnekleme yapılan noktalar

\subsection{Deneysel Çalışmalar}

KDPÜ Maden Mühendisliği Kendiliğinden Yanma Laboratuvarına getirilen örnekler, çeneli kırıcı ve halkalı değirmenden geçirilerek boyut küçültme işlemine tabi tutulmuş ve ardından tüm örnekler$75 \mu \mathrm{m}$ boyutuna indirilerek deneylere hazır hale getirilmiştir. Deneysel sürecin başlamasına kadar ki olan periyotta numuneler, oksitlenmeyi engellemek için kilitli poşetlere konularak derin dondurucuda muhafaza edilmiştir. $-75 \mu \mathrm{m}$ boyutuna indirgenen 21 adet kömür örneği, karelaj yöntemi ile her biri yaklaşık 400 gr olacak şekilde azaltılmış ve her numuneden yaklaşık 10 gr'lık bir kısım da örneklerin kısa ve elementel analizlerinin gerçekleştirilmesi için ayrılmıştır. Söz konusu analizler AB-0097-T no'lu akreditasyon sertifikasına sahip TKİ Garp Linyitleri İşletme Müdürlüğü Kömür Analiz Laboratuvarlarında yapılmıştır. Numunelere ait kısa ve elementel analiz sonuçları Çizelge 2'de verilmiştir. 
Çan Linyitleri İşletme Müdürlüğ̈̈ Açık Ocaklarında Üretilen Kömürlerin Stoklanması Sırasında Meydana Gelen Kendiliğinden Yanma Olayının Araştırılması

Çizelge 2. Kömür numunelerine ait kısa ve elementel analiz değerleri

\begin{tabular}{|c|c|c|c|c|c|c|c|c|c|c|c|}
\hline \multirow{3}{*}{ Numune } & \multicolumn{7}{|c|}{ Kısa Analiz } & \multicolumn{4}{|c|}{ Elementel Analiz } \\
\hline & $\begin{array}{c}\text { Nem } \\
(\%)\end{array}$ & $\begin{array}{l}\text { Kül } \\
(\%)\end{array}$ & $\begin{array}{c}\text { Uçucu } \\
\text { Madde } \\
(\%)\end{array}$ & $\begin{array}{c}\text { Sabit } \\
\text { Karbon } \\
(\%)\end{array}$ & $\begin{array}{c}\text { Alt } \\
\text { Kalori } \\
(\mathrm{cal} / \mathrm{g})\end{array}$ & $\begin{array}{c}\begin{array}{c}\text { Üst } \\
\text { Kalori } \\
\text { (cal/g) }\end{array} \\
\end{array}$ & $\begin{array}{c}\text { Toplam } \\
\text { Kükürt } \\
(\%)\end{array}$ & $\begin{array}{c}\mathrm{C} \\
(\%)\end{array}$ & $\begin{array}{c}\mathrm{H} \\
(\%)\end{array}$ & $\begin{array}{c}\mathrm{N} \\
(\%)\end{array}$ & $\begin{array}{c}\mathrm{O} \\
(\%)\end{array}$ \\
\hline & $\begin{array}{c}\text { ISO } 589 \\
\text { Metot B2 }\end{array}$ & $\begin{array}{l}\text { ASTM } \\
\text { D7582 }\end{array}$ & $\begin{array}{l}\text { ASTM } \\
\text { D7582 }\end{array}$ & $\begin{array}{l}\text { ASTM } \\
\text { D3172 }\end{array}$ & $\begin{array}{c}\text { TS EN } \\
\text { ISO } \\
1928 \\
\end{array}$ & $\begin{array}{l}\text { ASTM } \\
\text { D5865 }\end{array}$ & $\begin{array}{l}\text { ASTM } \\
\text { D4239 }\end{array}$ & $\begin{array}{l}\text { ASTM } \\
\text { D5373 }\end{array}$ & $\begin{array}{l}\text { ASTM } \\
\text { D5373 }\end{array}$ & $\begin{array}{l}\text { ASTM } \\
\text { D5373 }\end{array}$ & $\begin{array}{l}\text { ASTM } \\
\text { D3176 }\end{array}$ \\
\hline K-01 & 23,53 & 24,42 & 28,59 & 23,46 & 3123 & 3394 & 5,70 & 35,37 & 4,93 & 1,08 & 28,51 \\
\hline $\mathrm{K}-02$ & 19,61 & 30,92 & 27,73 & 21,75 & 2751 & 2987 & 7,27 & 31,08 & 5,53 & 1,02 & 24,18 \\
\hline K-03 & 20 & 30,81 & 27,52 & 21,67 & 2809 & 3049 & 6,57 & 32,60 & 4,10 & 1,01 & 24,91 \\
\hline K-04 & 19,19 & 25,03 & 31,13 & 24,65 & 3364 & 3622 & 6,24 & 38,80 & 4,68 & 1,13 & 24,11 \\
\hline K-05 & 18,18 & 29,59 & 33,15 & 19,07 & 3195 & 3453 & 6,82 & 37,20 & 5,75 & 1,01 & 19,63 \\
\hline K-06 & 17,69 & 37,38 & 28,41 & 16,52 & 2567 & 2794 & 5,84 & 30,54 & 4,94 & 0,96 & 20,34 \\
\hline K-07 & 16,04 & 35,83 & 28,45 & 19,68 & 2674 & 2891 & 6,61 & 31,64 & 5,16 & 0,93 & 19,83 \\
\hline K-08 & 12,57 & 56,26 & 20,97 & 10,20 & 1317 & 1465 & 3,76 & 16,53 & 3,54 & 0,93 & 18,99 \\
\hline K-09 & 14,19 & 50,26 & 22,44 & 13,11 & 1638 & 1805 & 4,57 & 20,65 & 4,12 & 0,80 & 19,60 \\
\hline K-10 & 10 & 68,26 & 18,18 & 3,56 & 512 & 620 & 1,55 & 8,91 & 2,57 & 0,88 & 17,84 \\
\hline K-11 & 13,94 & 59,11 & 20,16 & 6,78 & 938 & 1084 & 2,79 & 13,88 & 3,43 & 0,80 & 19,99 \\
\hline K-12 & 15,71 & 50,60 & 23,23 & 10,46 & 1570 & 1749 & 4,47 & 19,27 & 3,94 & 0,87 & 20,84 \\
\hline K-13 & 19,69 & 27,72 & 29,40 & 23,19 & 2972 & 3218 & 8,21 & 34,34 & 5,80 & 0,94 & 22,99 \\
\hline K-14 & 11,48 & 70,38 & 17,20 & 0,94 & 217 & 325 & 3,83 & 4,66 & 2,25 & 0,76 & 18,12 \\
\hline K-15 & 19,69 & 24,21 & 30,73 & 25,36 & 3249 & 3504 & 8,34 & 37,91 & 5,97 & 1,07 & 22,49 \\
\hline K-16 & 17,81 & 24,51 & 31,31 & 26,37 & 3475 & 3727 & 7,36 & 39,65 & 5,85 & 1,08 & 21,56 \\
\hline K-17 & 14,96 & 38,06 & 27,93 & 19,05 & 2463 & 2666 & 8,84 & 29,36 & 4,74 & 1,06 & 17,93 \\
\hline K-18 & 14,93 & 53,96 & 20,81 & 10,30 & 1299 & 1459 & 3,64 & 17,15 & 3,79 & 0,95 & 20,51 \\
\hline K-19 & 17,78 & 28,69 & 29,41 & 24,12 & 3090 & 3327 & 7,40 & 35,78 & 5,64 & 1,07 & 21,41 \\
\hline K-20 & 14,01 & 53,75 & 21,94 & 10,29 & 1265 & 1421 & 7,85 & 15,59 & 3,65 & 0,91 & 18,25 \\
\hline K-21 & 11,46 & 19,53 & 37,59 & 31,42 & 4169 & 4415 & 3,27 & 50,55 & 6,24 & 1,24 & 19,17 \\
\hline
\end{tabular}

4.3.1. Kendiliğinden Yanmaya Yatkınlık metodu (crossing point temperature method)" adı Testleri

verilen ve KDPÜ Maden Mühendisliği Bölümü Kendiliğinden Yanma Laboratuvarında hali

Çalıșma kapsamında temin edilen 21 adet örneğin kendiliğinden yanmaya yatkınlıklarının hazırda faaliyette olan deney seti vasitası ile belirlenmesi işlemi, literatürde "kesişim noktası gerçekleştirilmiştir. Söz konusu deney setine ait şematik gösterim Şekil 7'de verilmiştir.

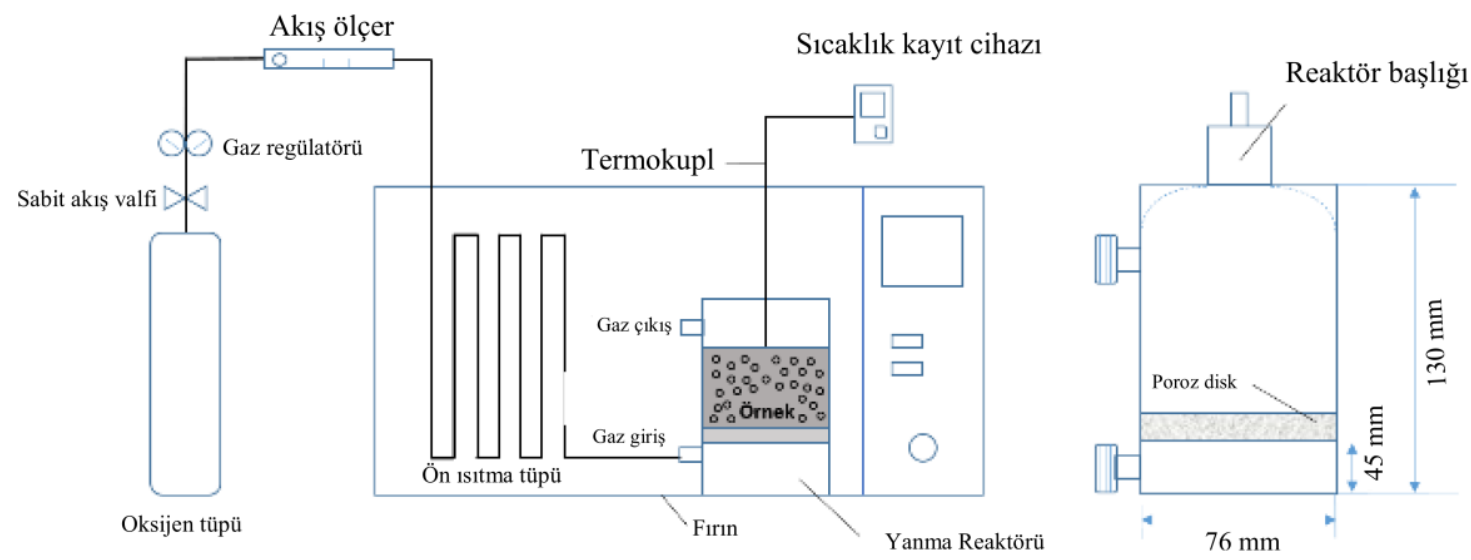

Şekil 7. Kendiliğinden yanma deney seti 
Kendiliğinden yanma deney seti; program ve rampa ayarlı bir etüv (Carbolite PF120, UK), akış ölçer (Cole Parmer, USA), sıcaklık kaydedici (Testo 175-T3, DE), oksijen ve azot tüpü ile kromnikel alaşımlı bir kömür reaktöründen meydana gelmektedir. Deneylerde yaklaşık 35 gr'lık kömür örneği kömür reaktörüne yerleştirilmekte ve gaz giriş ve çıkış bağlantıları yapıldıktan sonra rampa ayarlı etüv çalıştırılmaktadır. Etüv ve kömür örneğinin sıcaklıkları $30{ }^{\circ} \mathrm{C}$ 'de eşitleninceye kadar (stabilizasyon zamanı) reaktöre oksijen verilmemektedir. Kömür örneği $30{ }^{\circ} \mathrm{C}$ 'ye ulaştığ anda reaktöre $100 \mathrm{cc} / \mathrm{dk}$ 'lık oksijen verilerek deney başlatılmakta ve etüv ile kömür örneğinin zamana bağlı sıcaklık değişimleri takip edilmektedir.

Deney sirasinda elde edilen verilerden hareketle literatürde Feng, Chakravorty \& Cochrane ad1 verilen bir indeks yardımıyla kömürün kendiliğinden yanmaya yatkınlığg tespit edilmektedir [76].

Bahsi geçen indekse ait formülasyon ve formülasyon içinde kullanılan değişkenlere ait açıklamalar aşağıda verilmiştir [77] (Eşitlik 1).

$\mathrm{I}_{\mathrm{FCC}}=\frac{\text { Ortalama Sıcaklık Artışı (OSA) }}{\text { Tutuşma Sıcaklığ }} \times 1000$

Burada;

$\mathrm{I}_{\mathrm{FCC}}$ : Feng, Chakravorty, Cochrane indeksi, $\mathrm{dk}^{-1}$

OSA : $110-220^{\circ} \mathrm{C}$ arasındaki ortalama sicaklık artışı, ${ }^{\circ} \mathrm{C} \mathrm{dk}{ }^{-1}$

Ortalama sıcaklık artışı (OSA) ise (Eşitlik 2);

$\mathrm{OSA}=\frac{110}{\mathrm{t}_{2}-\mathrm{t}_{1}}$

formülü ile hesaplanmaktadır. Bu denklemde;

$\mathrm{t}_{2}$ : Kömür numunesinin $220{ }^{\circ} \mathrm{C}$ sıcaklığa ulaştığ1 zaman dakikası;

$\mathrm{t}_{1}$ : Kömür numunesinin $110{ }^{\circ} \mathrm{C}$ sıcaklığa ulaştığ1 zaman dakikasını ifade etmektedir.

\section{SONUÇLAR VE ÖNERILLER}

Çalışma, Türkiye Kömür İşletmeleri (TKİ) Çan Linyitleri İşletme Müdürlüğü (ÇLİ), Çanakkale ili, Çan ilçesi, IR:3378 ruhsat numaralı saha açık ocak işletmesine ait kömür üretim sahası ve kömür stoklarındaki kömürlerin kendiliğinden yanmaya yatkınlıklarının belirlenmesine yönelik olarak yürütülmüş olup kendiliğinden yanma deney sonuçları Çizelge 3'te verilmiştir. Buna göre çalışmada aşağıdaki sonuçlar elde edilmiştir;

1- Çalışma kapsamında A panosundan "16", hazırlık aşamasında olan B panosundan " 1 " ve iki ayrı stok sahasından "4" adet kömür numunesi temin edilmiş ve toplamda 21 adet örneğin kendiliğinden yanma yatkınlıkları kesişim noktası metodu ile belirlenmiştir. Buna göre kömürlerin ortalama sıcaklık artışları 0,92-3,93 ${ }^{\circ} \mathrm{C} / \mathrm{dk}$ arasında değişmektedir.

2- Söz konusu örneklerin tutuşma sicaklıkları 150-182 ${ }^{\circ} \mathrm{C}$ arasında değişirken, en düşük tutuşma sıcaklığına sahip yani kendiliğinden yanma açısından en yüksek risk içeren örnek K-04 olurken, en yüksek tutuşma sıcaklığına sahip yani kendiliğinden yanma açısından en az riske sahip örnek K-14 numunesi olmuştur.

3- Kendiliğinden yanma risk indeksinin hesaplanmasinda Feng, Chakravorty \& Cochrane indeksi ( $\mathrm{I}_{\mathrm{FCC}}$ ) kullanılmıştır. $\mathrm{Bu}$ indeks değerine göre elde edilen sonuçlardan kömürler "orta-yüksek" risk kategorisi altında farklı değerler almıştır. En yüksek risk değerine 33,33 1/dk değeri ile K-04 örneği sahip olurken, en az risk değeri 5,04 1/dk değeri ile K-14 örneğine aittir.

Elde edilen sonuçlardan hareketle; Türkiye Kömür İşletmeleri Çan Linyitleri İşletmesi Müdürlüğü Çanakkale İli, Çan İlçesi, IR:3378 ruhsat numaralı saha açık ocak işletmesine ait kömür üretim sahası ve kömür stoklarından temin edilen 21 adet kömür örneğinin kendiliğinden yanmaya yatkınlıklarının "orta-yüksek" risk kategorisinde yer aldığı belirlenmiştir. 
Çan Linyitleri İşletme Müdürlüğ̈̈ Açık Ocaklarında Üretilen Kömürlerin Stoklanması Sırasında Meydana Gelen Kendiliğinden Yanma Olayının Araştırılması

Çizelge 3. Tüm örneklere ait kendiliğinden yanma deney sonuçları

\begin{tabular}{|c|c|c|c|c|c|c|c|c|c|}
\hline Numune & $\begin{array}{c}\text { Ortalama } \\
\text { Sıcaklık Artış1 } \\
(\mathrm{OSA}) \\
\left({ }^{\circ} \mathrm{C} \mathrm{dk}^{-1}\right)\end{array}$ & $\begin{array}{c}\text { Kesiş̧im } \\
\text { Noktası } \\
\text { Sicaklığı } \\
(\mathrm{KNS})\left({ }^{\circ} \mathrm{C}\right)\end{array}$ & $\begin{array}{c}\text { Yatkınlık } \\
\text { İndeksi } \\
\left(\mathrm{I}_{\mathrm{FCC}}\right) \\
\left(\mathrm{dk}^{-1}\right)\end{array}$ & $\begin{array}{c}\text { Yanma } \\
\text { Riski }\end{array}$ & Numune & $\begin{array}{c}\text { Ortalama } \\
\text { Sıcaklık Artış1 } \\
\text { (OSA) } \\
\left({ }^{\circ} \mathrm{C} \mathrm{dk}^{-1}\right)\end{array}$ & $\begin{array}{c}\text { Kesiş̧im } \\
\text { Noktası } \\
\text { Sıcaklığı } \\
(\mathrm{KNS})\left({ }^{\circ} \mathrm{C}\right)\end{array}$ & $\begin{array}{c}\text { Yatkınlık } \\
\text { İndeksi } \\
\left(\mathrm{I}_{\mathrm{FCC}}\right) \\
\left(\mathrm{dk}^{-1}\right)\end{array}$ & $\begin{array}{c}\text { Yanma } \\
\text { Riski }\end{array}$ \\
\hline K-01 & 1,527777778 & 153 & 9,985475672 & orta & $\mathrm{K}-11$ & 1,692307692 & 160 & 10,57692308 & yüksek \\
\hline K-02 & 3,333333333 & 151 & 22,07505519 & yüksek & K-12 & 2,558139535 & 156 & 16,39833035 & yüksek \\
\hline K-03 & 3,793103448 & 151 & 25,11989039 & yüksek & K-13 & 3,142857143 & 151 & 20,81362346 & yüksek \\
\hline K-04 & 5 & 150 & 33,33333333 & yüksek & K-14 & 0,916666667 & 182 & 5,036630037 & orta \\
\hline K-05 & 1,358024691 & 154 & 8,818342152 & orta & K-15 & 3,235294118 & 154 & 21,00840336 & yüksek \\
\hline K-06 & 3,055555556 & 155 & 19,71326165 & yüksek & K-16 & 3,142857143 & 153 & 20,54154995 & yüksek \\
\hline K-07 & 3,928571429 & 153 & 25,67693744 & yüksek & K-17 & 2,444444444 & 151 & 16,1883738 & yüksek \\
\hline K-08 & 1,896551724 & 155 & 12,23581758 & yüksek & K-18 & 2,075471698 & 156 & 13,30430576 & yüksek \\
\hline K-09 & 2,291666667 & 152 & 15,07675439 & yüksek & K-19 & 3,548387097 & 152 & 23,34465195 & yüksek \\
\hline \multirow[t]{2}{*}{ K-10 } & 0,982142857 & 170 & 5,777310924 & orta & K-20 & 2,340425532 & 156 & 15,00272777 & yüksek \\
\hline & & & & & K-21 & 2,682926829 & 151 & 17,76772735 & yüksek \\
\hline
\end{tabular}

\section{TEŞEKKÜR}

Yazarlar yapılan çalışmada gösterdikleri yardım ve desteklerden dolayı Türkiye Kömür İşletmeleri Genel Müdürlüğü ve Çan Linyitleri İşletmesi Müdürlüğü yetkililerine sonsuz teşekkürlerini sunar.

\section{KAYNAKLAR}

1. Carras, J. N., Day, S. J., Saghafi, A., Williams, D.J., 2009. Greenhouse Gas Emissions from Low-Temperature Oxidation and Spontaneous Combustion at Open-Cut Coal Mines in Australia. International Journal of Coal Geology, 78(2), 161-168.

2. Wang, H., Chen, C., 2015. Experimental Study on Greenhouse Gas Emissions Caused By Spontaneous Coal Combustion. Energy and Fuels, 29(8), 5213-5221.

3. Fierro, V., Miranda, J.L., Romero, C., Andrés, J.M., Arriaga, A., Schmal, D., Visser, G.H., 1999. Prevention of Spontaneous Combustion in Coal Stockpiles: Experimental Results in Coal Storage Yard. Fuel Processing Technology, 59(1), 23-24.

4. Arisoy, A., Beamish, B., Çetegen, E., 2006. Modelling Spontaneous Combustion of Coal. Turkish Journal of Engineering and Environmental Sciences, 30, 193-201.

5. Pone, J.D.N., Hein, K.A.A., Stracher, G.B., Annegarn, H.J., Finkleman, R.B., Blake, D.R., McCormack, J.K., Schroeder, P., 2007. The Spontaneous Combustion of Coal and its ByProducts in the Witbank and Sasolburg
Coalfields of South Africa. International Journal of Coal Geology, 72(2), 124-140.

6. Muduli, L., Jana, P.K., Mishra, D.P., 2018. Wireless Sensor Network Based Fire Monitoring in Underground Coal Mines: A Fuzzy Logic Approach. Process Safety and Environmental Protection, 113, 435-447.

7. Wachowicz, J., 2008. Analysis of Underground Fires in Polish Hard Coal Mines. Journal of China University of Mining and Technology, 18(3), 332-336.

8. Xia, T., Zhou, F., Wang, X., Zhang, Y., Li, Y., Kang, J., Liu, J., 2016. Controlling Factors of Symbiotic Disaster Between Coal Gas and Spontaneous Combustion in Longwall Mining Gobs. Fuel, 182, 886-896.

9. Kong, B., Li, Z., Yang, Y., Liu, Z., Yan, D., 2017. A Review on the Mechanism, Risk Evaluation, and Prevention of Coal Spontaneous Combustion in China. Environmental Science and Pollution Research, 24(30), 23453-23470.

10. Singh, R.V.K., 2013. Spontaneous Heating and Fire in Coal Mines. Procedia Engineering, 62, 78-90.

11. Mohalik, N.K., Lester, E., Lowndes, I.S., Singh, V.K., 2016. Estimation of Greenhouse Gas Emissions from Spontaneous Combustion/Fire of Coal in Opencast Mines-Indian Context. Carbon Management, 7(5-6), 317-332.

12. Nimaje, D.S., Tripathy, D.P., 2016. Characterization of Some Indian Coals to Assess Their Liability to Spontaneous Combustion. Fuel, 163, 139-147.

13. Wang, L., Ren, T., Nie, B., Chen, Y., Lv, C., 
Tang, H., Zhang, J., 2015a. Development of a Spontaneous Combustion Tarps System Based On BP Neural Network. International Journal of Mining Science and Technology, 25(5), 803-810

14. Liang, Y., Zhang, J., Ren, T., Wang, Z., Song, S., 2018. Application of Ventilation Simulation to Spontaneous Combustion Control in Underground Coal Mine: A Case Study From Bulianta Colliery. International Journal of Mining Science and Technology, 28, 231-242.

15. Onifade, M., Genc, B., 2019. A Review of Spontaneous Combustion Studies-South African Context. International Journal of Mining, Reclamation and Environment, 33(8), 527-547.

16. Taraba, B., Michalec, Z., 2011. Effect of Longwall Face Advance Rate on Spontaneous Heating Process in the Gob Area-CFD Modelling. Fuel, 90(8), 2790-2797.

17. Taraba, B., Michalec, Z., Michalcová, V., Blejchař, T., Bojko, M., Kozubková, M., 2014. CFD Simulations of the Effect of Wind on the Spontaneous Heating of Coal Stockpiles. Fuel, 118, 107-112.

18. De Rosa, M. I., 2004. Analysis of Mine Fires for All USA Underground and Surface Coal Mining Categories:1990-1999. U.S. Department of Health and Human Services, Centers for Disease Control and Prevention, National Institute for Occupational Safety And Health (NIOSH), Pittsburgh Research Laboratory Pittsburgh, PA, $35 \mathrm{~s}$.

19. Nugroho, Y.S., McIntosh, A.C., Gibbs, B.M., 1998. Using the Crossing Point Method to Assess the Self-Heating Behavior of Indonesian Coals. Twenty-Seventh Symposium (International) on Combustion/The Combustion Institute, 27(2), 2981-2989.

20. Hogland, W., Bramryd, T., Persson, I., 1996. Physical, Biological and Chemical Effects of Unsorted Fractions of Industrial Solid Waste in Waste Fuel Storage. Waste Management \& Research, 14, 197-210.

21. Hogland, W., Marques, M., 2003. Physical, Biological and Chemical Processes During Storage and Spontaneous Combustion of Waste Fuel. Resources, Conservation and Recycling, 40(1), 53-69.

22. Pis, J., de la Puente, G., Fuente, E., Morán, A.,
Rubiera, F., 1996. A Study of the Self-Heating of Fresh and Oxidized Coals by Differential Thermal Analysis. Thermochimica Acta, 279, 93-101.

23. Zhu, H., Song, Z., Tan, B., Hao, Y., 2013. Numerical Investigation and Theoretical Prediction of Self-Ignition Characteristics of Coarse Coal Stockpiles. Journal of Loss Prevention in the Process Industries, 26(1), 236-244.

24. Qi, X., Wang, D., Zhong, X., Gu, J., Xu, T., 2010. Characteristics of Oxygen Consumption of Coal at Programmed Temperatures. Mining Science and Technology (China), 20(3), 372-377.

25. Carras, J.N., Young, B.C., 1994. Self-Heating of Coal and Related Materials: Models, Application and Test Methods. Progress in Energy and Combustion Science, 20(1), 1-15.

26. Wang, H., Dlugogorski, B.Z., Kennedy, E.M., 2003b. Pathways for Production of $\mathrm{CO}_{2} \& \mathrm{CO}$ in Low-Temperature Oxidation of Coal. Energy \& Fuels, 17(1), 150-158.

27. Gürdal, G., Hoşgörmez, H., Özcan, D., Li, X., Liu, H., Song, W., 2015. The Properties of Çan Basin Coals (Çanakkale-Turkey): Spontaneous Combustion and Combustion By-Products. International Journal of Coal Geology, 138, 1-15.

28. Wang, Y., Shi, G., Guo, Z., 2015b. Coupled Multi-Stage Oxidation and Thermodynamic Process in Coal-Bearing Strata Under Spontaneous Combustion Condition. International Symposium on Advances in Computational Heat Transfer, Rutgers University, Piscataway, NJ, USA, 1-12.

29. Wang, H., Dlugogorski, B.Z., Kennedy, E.M., 2003a. Coal Oxidation at Low Temperatures: Oxygen Consumption, Oxidation Products, Reaction Mechanism and Kinetic Modelling. Progress in Energy and Combustion Science, 29(6), 487-513.

30. Nelson, M., Chen, X.D., 2007. Survey of Experimental Work on the Self-Heating and Spontaneous Combustion of Coal. Geology of Coal Fires: Case Studies From Around the World: Geological Society of America Reviews in Engineering Geology, XVIII, 31-83.

31. Nalbandian, H., 2010. Propensity of Coal to SelfHeat. International Energy Agency, Clean Coal 
Çan Linyitleri Işsletme Müdürlüğ̈̈ Açık Ocaklarında Üretilen Kömürlerin Stoklanması Sırasında Meydana Gelen Kendiliğinden Yanma Olayının Araştırılması

Centre, 45 .

32. Shi, T., Wang, X., Deng, J., Wen, Z., 2005. The Mechanism at the Initial Stage of the RoomTemperature Oxidation of Coal. Combustion and Flame, 140(4), 332-345.

33. Wang, H., Dlugogorski, B.Z., Kennedy, E.M., 2003. Analysis of the Mechanism of the LowTemperature Oxidation of Coal. Combustion and Flame, 134(1-2), 107-117.

34. İnal, S., Aydıner, K., 2019. Kömürün Kendiliğinden Yanması ve Etkileyen Faktörler. Bilimsel Madencilik Dergisi, 58(2), 145-165.

35. Güney, M., 1968. Certain Factors Affecting the Oxidation and Spontaneous Combustion of Coal. University of Nottingham, Mining Department Magazine, 20, 71 - 80.

36. Kural, O., 1991. Kömür, Kurtiş Matbaası. 976s.

37. Kural, O., 1998. Kömür Özellikleri, Teknolojisi ve Çevre İlişkileri. Özgün Ofset Matbaacılık A.Ş., 785.

38. Uludağ, S., 2001. Assessing Spontaneous Combustion Risk in South African Coal Mines Using a GIS Tool. M.Sc Dissertation, University of Witwatersrand, South Africa.

39. Kaymakçi, E., Didari, V., 2002. Relations Between Coal Properties and Spontaneous Combustion Parameters. Turkish Journal of Engineering and Environmental Sciences, 26(1), 59-64.

40. Ramlu, M.A., 1991. Mine Disasters and Mine Rescue. A.A. Balkema, Rotterdam, 397.

41. Önal, G., Ateşok, G., Perek, K.T., 2014. Cevher Hazırlama El Kitabı. Yurt Madenciliğini Geliştirme Vakfı Yayınları, İstanbul.

42. Coward, H.F., 1957. Research on Spontaneous Combustion of Coal in Mines-a Review. Research Report 142, Great Britain: Safety in Mines Research Establishment.

43. Chamberlain, E.A.C., Hall, D.A., 1973. The Liability of Coals to Spontaneous Combustion. Colliery Guardian, 65-72.

44. Allardice, D.J. Evans, D.G., 1978. Moisture in Coal, in C. Karr, Jr_ (Ed.), Analytical Methods for Coal and Coal Products. Vol 1, Academic Press, New York, 247-262.

45. Kemal, M., Arslan, V., 2010. Kömür Teknolojisi. Genişletilmiş 5.bask1, Dokuz Eylül Üniversitesi Mühendislik Fakültesi Yayınları, 033, İzmir.

46. Beamish, B.B., Hamilton, G.R., 2005. Effect of
Moisture Content on the R70 Self-Heating Rate of Callide Coal. International Journal of Coal Geology, 64, 133-138.

47. Panaseiko, N.P., 1974. Influence of Moisture on the Low Temperature Oxidation of Coals. Solid Fuel Chemistry, 8, 21-24.

48. Chen, X.D., Stott, J.B., 1993. The Effect of Moisture Content on the Oxidation Rate of Coal During Near-Equilibrium Drying and Wetting at $50{ }^{\circ} \mathrm{C}$. Fuel, 72, 787-792.

49. Kadioglu, Y., Varamaz, M., 2003. The Effect of Moisture Content and Air-Drying on Spontaneous Combustion Characteristics of Two Turkish Lignites. Fuel, 82, 1685-1693.

50. Akgün, F., Arisoy, A. ,1994. Effect of Particle Size on the Spontaneous Heating of a Coal Stockpile. Combustion and Flame, 99(1), 137-146.

51. Ren, T.X., Edwards, J.S., Clarke, D., 1999. Adiabatic Oxidation Study on the Propensity of Pulverised Coals to Spontaneous Combustion. Fuel, 78(14), 1611-1620.

52. Küçük, A., Kadıŏlu, Y., Gülaboğlu, M.Ş., 2003. A Study of Spontaneous Combustion Characteristics of a Turkish Lignite: Particle Size, Moisture of Coal, Humidity of Air. Combustion and Flame, 133, 255-261.

53. Didari, V., 1986. Yeraltı Ocaklarında Kömürün Kendiliğinden Yanması ve Risk İndeksleri. Madencilik Dergisi, 25, 4.

54. Jena, S.S., 2011. Investigation in to Spontaneous Combustion Characteristics of Some Indian Coalsand Correlation Study with Their Intrinsic Properties. Bachelor Degree, Department of Mining Engineering National Institute of Technology Rourkela.

55. Barış, K., 2010. Farklı Kömürleşme Derecesine Sahip Kömürlerde Düşük Sıcaklık Oksidasyonu. Doktora Tezi, Fen Bilimleri Enstitüsü, Zonguldak Karaelmas Üniversitesi, Zonguldak.

56. Durucan, Ş., Güyagüler, T., 1985. Yeraltı Madenciliğinde Çevre Sorunları ve Kontrol Yöntemleri. Genel Maden İşçileri Yayını.

57. Arisoy, A., Beamish, B., 2015. Mutual Effects of Pyrite and Moisture on Coal Self-Heating Rates and Reaction Rate Data for Pyrite Oxidation. Fuel, 139, 107-114.

58. Beamish, B., Lin, Z., Beamish, R., 2012. Investigating the Influence of Reactive Pyrite on 
Coal Self-Heating. Proceedings of the Twelfth Coal Operators Conference, Wollongong, 294299.

59. Stracher, G.B., Prakash, A., Ellina, V.S., 2010. Coal and Peat Fires - a Global Perspective. vol.I: coal, geology and combustion, 343s.

60. Falcon, R.M., 1986. Spontaneous Combustion of The Organic Matter in Discards from the Witbank Coalfield. Journal of South African Institute of Mining and Metallurgy, 86, 243-250.

61. Barış, K., Kızgut, S., Didari, V., 2012. LowTemperature Oxidation of Some Turkish Coals. Fuel, 93, 423-432.

62. Özdeniz, A.H., 2003. Kömür Stoklarındaki Kendiliğinden Yanma Olayının İncelenmesi. Doktora Tezi, Fen Bilimleri Enstitüsü, Selçuk Üniversitesi, Konya.

63. Sen, R., Srivastava, S.K., Singh, M.M., 2009. Aerial Oxidation of Coal-Analytical Methods, Instrumental Techniques and Test Methods: A Survey. Indian Journal of Chemical Technology, 16, 103-135.

64. Schmidt, L.D., Elder, J.L., 1940. Atmospheric Oxidation of Coal at Moderate TemperaturesRates of the Oxidation Reaction for Represantative Coking Coals. Industrial and Engineering Chemistry, 32(2), 249-256.

65. Chamberlain, E.A., Hall, D.A., Thirlaway, J.T., 1970. The Ambient Temperature Oxidation of Coal in Relation to the Early Detection of Spontaneous Heating. Mining Engineer, 130, $1-16$.

66. Chamberlain, E.A., Barrass, G., Thirlaway, J.T., 1976. Gases Evolved and Possible Reactions During Low Temperature Oxidation of Coal. Fuel, 55, 217-222.

67. Gill, F., Browning, E., 1971. Spontaneous Combustion in Coal Mines. Colliery Guardian, 219, 79-85.

68. Mahadevan, V., Ramlu, M., 1985. Fire Risk Rating of Coal Mines due to Spontaneous Heating. Journal of Mines, Metals and Fuels, 33, 357-362.

69. Morris, R., Atkinson, T., 1986. Geological and Mining Factors Affecting Spontaneous Heating of Coal. Mining Science and Technolgy, 3, 217-231.

70. Banerjee, S.C., 1985. Spontaneous Combustion of Coal and Mine Fires. A.A. Balkema/
Rotterdam, 167.

71. Kural, O., 1988. Kömür Kimyası ve Teknolojisi. 657.

72. Erkan, H., 1964. Kömürün Depolanmas1. Madencilik, 3, 12-13.

73. Karpuz, C., Güyagüler, T., Bağcı, S., Bozdağ, T., Başarır, H., Keskin, S., 2000. Linyitlerin Kendiliğinden Yanmaya Yatkınlık Derecelerinin Tespiti: Bölüm I - Risk Sınıflaması Derlemesi. Madencilik Dergisi, Eylül/Aralık, 3-13.

74. Yılmaz, A.İ., 2002. Eynez Yeraltı Ocağ 1 Havalandırma Sisteminin Ocak Yangınlarına Etkisi. Doktora Tezi, Fen Bilimleri Enstitüsü, Dokuz Eylül Üniversitesi, İzmir.

75. www.cli.gov.tr

76. Feng, K.K., Chakravorty, R.N., Cochrane, T.S., 1973. Spontaneous Combustion-a Coal Mining Hazard. The Canadian Mining and Metallurgical Journal.

77. Ören, Ö., Şensöğüt, C., 2007. Kütahya Bölgesi Linyitlerinin Kendiliğinden Yanmaya Yatkınlıklarının Araştırılması. Madencilik, 46(1), 15-23. 
